\title{
Notes on the language of Marcus Caelius Rufus
}

\author{
Harm Pinkster
}

Marcus Caelius Rufus (c. $88-48$ BC) is the author of seventeen letters to Cicero preserved in Book 8 of Cicero's Epistulae ad familiares, totalling thirty pages in the Oxford Classical Text. ${ }^{I}$ We also possess nine letters of Cicero to Caelius (Fam. 2.8-16, eighteen pages OCT), three of which are reactions to preserved letters of Caelius. I will be concerned with those letters that were exchanged between the two when Cicero was proconsul in Cilicia (fifteen letters by Caelius - total number of words $5,275^{2}$ - and eight by Cicero - 2,OII words), written between May 5I BC and November 50 вс. The size of the two corpora is large enough and the circumstances in which they were writing were sufficiently stable to see whether there are differences between the language of the two men.

Caelius had a good reputation as orator, as is testified by Cicero himself and by Quintilian: ${ }^{3}$

$\dagger$ quam eius actionem $\dagger$ multum tamen et splendida et grandis et eadem in primis faceta et perurbana commendabat oratio. graves eius contiones aliquot fuerunt, acres accusationes tres eaeque omnes ex rei publicae contentione susceptae; defensiones, etsi illa erant in eo meliora quae dixi, non contemnendae tamen saneque tolerabiles. (Cic. Brut. 273, my emphasis)

His delivery was offset by a style brilliant and impressive, conspicuous especially for its cleverness and wit. He made some important public speeches and three merciless prosecutions, all of which arose out of political ambition and rivalry. His court speeches in defence of himself and others, although inferior to those which I have mentioned, were not negligible, indeed quite tolerable. (trans. H. M. Hubbell, Loeb)

\footnotetext{
I The author would like to thank the anonymous referee and Eleanor Dickey for their very helpful comments and suggestions.

2 The senatus consulta in Cael. Fam. 8.8.5-8 are not in this total.

3 There is a detailed discussion of Caelius as an orator in Cavarzere 1983: 46-6I.
} 
multum ingenii in Caelio et praecipue in accusando multa urbanitas, dignusque vir cui et mens melior et vita longior contigisset. (Quint. Inst. Io.I.II5, my emphasis)

Caelius had much talent, and a notable wit, especially in prosecuting; he deserved a wiser mind and a longer life. (trans. D. A. Russell, Loeb)

Quintilian (Inst. 4.2.123-4) quotes one longer passage of Caelius (Malcovati 1976: no. 162.I7: four sentences, seventy-five words) to illustrate the technique of 'combining the true facts with a plausible picture of the scene' qualis est illa M. Caeli in Antonium descriptio 'such as that well known description of M. Caelius that he used against Antonius', which he then qualifies in the following way: 'Nothing can be more plausibly invented, more strongly censured, or more vividly portrayed.' ${ }^{4}$

Aper, in Tacitus, Dialogus 2I.4, while recognising Caelius' qualities in general (the speeches manifest the nitor 'elegance' and the altitudo 'sublimity of style' that was typical of his time), mentions a few characteristics of Caelius' speeches he considers less positive: sordes verborum 'unrefined words', hians compositio 'disjointed arrangement of the words' and inconditi sensus 'shapeless periods' (see Mayer 200I: 156-7).

The fragments from the speeches that we have, including the longer one mentioned, do not allow a linguistic comparison with the letters. We have no ancient comments on the language of the letters of Caelius (nor on the language of Cicero's, apart from Fronto's general remark quoted in note I2). We can be pretty sure that the language of the letters we have would not qualify as splendida or grandis (but satirical wit is definitely present), whereas Aper's qualifications might be pertinent to some extent. However, the evaluations quoted above prove beyond doubt that the quality of the language of the letters, whatever it is, is not due to an insufficient command of the Latin language, to an insufficient education (in fact, his apprenticeship on the forum was supervised by Cicero and M. Licinius Crassus), or any similar cause. Like any language user Caelius must have been able to adapt his language to the circumstances (the reader, the topics he was writing about, and the communicative goal(s) of his letters). ${ }^{5}$ We may even assume that his ability to adapt was more than average, given his training and education. We therefore can a priori assume that allowing for one or two slips of the pen (and imperfections in the manuscript tradition) the wording of the letters is what Caelius considered adequate in the circumstances.

4 Trans. D. A. Russell (Loeb).

5 I paraphrase Quirk et al. (1985: 25-7) in their section 'Varieties [of English] according to attitude'. 
What were the circumstances? ${ }^{6}$ When Cicero left for his province he asked Caelius to keep him informed of the situation in Rome (Cael. Fam. 8.I.I), more specifically about those developments that were relevant to Cicero himself (Cic. Fam. 2.8.I). The function of the letters was not so much to give an ordered account of the actual events in Rome (Caelius tells us (Fam. 8.I.I) that he had someone else write a detailed report in addition to his own letters; the verbatim reports in 8.8.5-8 are an exception), but to report Caelius' personal estimate of the situation and of the events to come (Fam. 2.8.I). The letters were certainly not meant for circulation. Given the intimate relationship that existed between the two men and the type of information the letters contained Caelius most likely adopted an informal variety of Latin, a type of letter that Cicero elsewhere called familiare et iocosum 'informal and gossiping' (Fam. 2.4.I). With other correspondents Caelius probably used a more formal or neutral variety of Latin, in the same way as Cicero's letters vary depending on which correspondents they were addressed to. ${ }^{7}$ However, Caelius was writing to Cicero, the orator of his time, then still an important statesman, a generation older than Caelius himself, and Caelius was an ambitious young man. There is no reason to assume that by choosing an informal variety he could afford to be negligent or go as far as using slang.

The topics include political events (notably the delicate relationship between Caesar and Pompey), social events (accusations and prosecutions, divorces and adultery), family affairs, Caelius' anxiousness to obtain panthers for his Games, his worries about the Parthian situation, etc. Some are more serious than others, some require more detail and precision of description, and some are more 'technical' and require the use of less common words and expressions. Some topics lend themselves more readily to a narrative mode of discourse than others. Caelius' language varies with the topics he addresses, as a comparison of his carefully worded advice in Fam. 8.6.I and his gossip in 8.7.2 will easily demonstrate.

Cicero's letters are mostly reactions to Caelius' reports and they vary with the topics as well. A good example is Cicero's reaction (Fam. 2.13.3) to Caelius' last-minute modification of the first part of his letter (Fam. 8.6.5). Now and then he writes in detail about his daily activities. An example is the passage about his actions as a commander against an expected Parthian attack (Fam. 2.I0.2-3), which can be read as a first draft of the official report he plans to send to Rome later, when the campaign will be finished

\footnotetext{
6 See Hutchinson 1998: I4I-8 on the context of Cael. Fam 8.6.

7 See Albrecht's section 'Types of letters' (2003: 67-7I) and Hutchinson 1998: 7-8.
} 
successfully. It contains the only ablative absolute, a typical feature of the narrative mode, ${ }^{8}$ in these letters: Parthico bello nuntiato 'after news had arrived about the Parthian war'.

A few words about the medium, (letter) writing. If any form of writing is really written and not spoken language it is letter writing. Whereas written plays, orations and dialogues try to convey a sufficient number of linguistic features to suggest oral communication, this is not the case in letter writing (unless it contains a report of a conversation). Informal writing does not per se imply the use of features that are typical of spoken language. There is informal and formal writing alongside informal and formal speaking. Letters written by or for uneducated people or people with an insufficient knowledge of Latin are also written language (see Halla-aho 2009). One should therefore be careful with the use of terms like 'colloquial'.?

Caelius' letters were dictated, with an occasional addition in Caelius' own handwriting (8.6.5 is such an addition, as we know from Cic. Fam. 2.13.3). This might have left 'oral' traces in the language of the letters. Speculative candidates are the few harsh asyndeta mentioned by Burg (I888: 72) and Cavarzere (1983: 67). Burg says that with his 'frequent' use of asyndeton Caelius follows the 'sermonis antiqui et vulgaris simplicitatem', but he adds 'simulque eo consilio ut graviorem concitatioremque orationem faciat'. One of his examples is:

[Laterensis] in tabulas absolutum non rettulit, ordinum iudicia perscripsit. (Cael. Fam. 8.8.3)

Laterensis made his entry in the record - not 'acquitted', but the verdicts of the several categories. (trans. D. R. Shackleton Bailey, Loeb)

In spoken language the contrast between the two clauses would appear from the intonation contour. However, dictated written language is not equivalent to recorded spoken language. Unlike recorded language, dictated language is intended to be read by another person. Instead of taking the asyndeton quoted above as the mechanical notation of an unintended asyndeton I assume that Caelius had the choice between dictating a syndetic and an asyndetic version and that he preferred the latter, perhaps to achieve

${ }^{8}$ On this letter and other 'military narrative' passages in Cicero's letters see Hutchinson I998: 80-IOo. For the use of the ablative abs. in narrative (letters and orations) in Cicero see Van Gils 2003: 54-7.

9 Of course 'literary' letters also existed in antiquity. On Cicero's plans to introduce this genre in Rome and make a selection (and adaptation) of his own letters see Cavarzere 2007: 35-40. Letters that were not meant for publication as literary may nevertheless have aesthetic or artistic aspirations and qualities; see Hutchinson 1998 on Cicero's letters. For common characteristics of Cicero's letters and the 'documentary' letters found in Vindolanda and elsewhere see Cugusi 1998: 174-85. 
the effect mentioned by Burg. Instead of being simple, it may just as well be refined.

Modern scholars vary in their appreciation of the language of Caelius' letters. Badian (OCD s.v. Caelius) calls it 'a delightful, informal style'. Hutchinson (1998: I42) mentions Caelius' 'obvious literary talent'. Shackleton Bailey, in his commentary on the Epistulae ad familiares, is less charmed by Caelius' language. He blames Caelius' 'careless writing' (ad 8.14.4), talks of a 'happy-go-lucky style' (ad 8.4.2), and observes that 'limits can hardly be set to the vagaries of such a writer as Caelius' (ad 8.4.3). Other scholars refrain from terms like the ones mentioned while describing the language as the product of, on the one hand, the intimate relationship between Caelius and Cicero and the content of the letters, and on the other hand Caelius' age and character (e.g. Leeman 1963: 137-8). The result of these factors is a variety of language with many elements that are regarded as reflections of spontaneous, spoken language, in other words: 'colloquialisms'. A survey of 'colloquialisms', more or less along the lines of Hofmann (195I), can be found in Cavarzere (1983: 62-78). More details can be found in Becher (I888) and Burg (I888). However, as Cavarzere (1983: 7I) rightly observes, many of the elements mentioned are not typical of Caelius. They are also common in Cicero's letters and in those of his other correspondents. Has Caelius more or less, or a different mix, of these elements? Or are there levels of colloquialism and has Caelius (more) expressions belonging to a lower level (see above: sordes verborum)?

The lexicon is perhaps the area that has attracted most attention, and at first sight it is a relatively unproblematic topic that yields clear results. Lebek (1970: 134) mentions fourteen words used by Caelius that are entirely absent from the works of Cicero, his correspondents, and Caesar. He concludes: 'Jedoch scheinen die Lizenzen des Briefschreibers [i.e. Caelius] ... über das sonst im familiären sermo der guten Gesellschaft Übliche bisweilen hinauszugehen.' Plausible as this may seem (one word in every two pages), how does one reconcile it with the fact that in his first letter to Caelius (Fam. 2.8.I) Cicero, while joking about the extensiveness of the report that Caelius attaches to his letters (see above), uses the hapax compilatio 'burglary' and the unique combination gladiatorum compositiones 'pairings of gladiators'? Observations on the distribution of a word as such are not sufficient. In the first place, there is nothing to prevent Caelius (or anybody) inventing a new word and it need not be (very) informal on that account. Secondly, there is also nothing to prevent Caelius using a word that is (mainly) attested outside classical prose. It may have been the most 
appropriate word in the context, because there was no synonym available, because it was the right expression in the semantic field at hand, or because it evoked the connotation that suited best. Two words may serve as an illustration.

In Fam. 8.I.4 Caelius tells Cicero that subrostrani 'people who lounge near the Rostra (sub rostris), city loafers' (OLD's translation) had spread the news that Cicero was dead. As to its formation and its meaning the word is fully transparent: it resembles suburbanus 'situated close to the city', which is common enough in all sorts of texts from Cato onwards. ${ }^{\text {IO }}$ The word was certainly not meant as a compliment by Caelius. We will probably never know whether it was Caelius' invention nor whether it was used in informal speech. In the same paragraph Caelius uses the unique expression embaeneticam [sc. artem] facere for Q. Pompeius. The precise meaning of embaenetica is unclear, ${ }^{\mathrm{II}}$ though the adjective must be derived from the


Shackleton Bailey (1977: 384) translates 'operating boats', Constans (I936: 220) 'promener des touristes en barques'. Whatever it meant, the job that Pompeius was said to be performing in Bauli was certainly not one that befitted a man of his position. Here again Caelius may have invented the expression for the occasion or taken it from a semantic field that is not well represented in our corpus of texts. The expression may have been intended as denigratory. This does not make it informal or, even worse, vulgar. It may have been clever instead. Cicero jokingly asked Verres whether people were to assume naviculariam, cum Romam venisses, esse facturum 'that you were going into the shipping business when you reached Rome' (Ver. 5.46) (trans. L. H. G. Greenwood, Loeb), another unique expression and not, for that reason, informal. It is also not easy to think of synonyms for the two words discussed. Caelius did not choose an informal wording from a set of alternatives, at least as far as we know.

Reading through a very detailed commentary like the one by Cavarzere, one sometimes gets the impression that, if we acted in the same way with Cicero, we would find a lot of 'unclassical' expressions. ${ }^{12}$ Just one example: in his first letter to Caelius, already referred to, Cicero uses the expression

Io For derivatives in -anus see Kircher-Durand 2002: 133-6.

II The $O L D$ calls it 'probably corrupt'; for the history of scholarship see Cavarzere 1983: 209-IO, adding W. Schneider 2000: 516-18.

${ }^{12}$ That may have been the reason why Fronto was of the opinion that one should read 'all letters of Cicero', even more so than 'all his orations', because 'there is nothing more perfect than Cicero's letters' (Fro. Ant. 3.Io, pp. I07-8 van den Hout). For other statements on or imitiations of Cicero in antiquity see Cugusi 1998: 167-70. 
decem ipsos dies 'exactly ten days' (Fam. 2.8.3). ${ }^{\mathrm{I3}}$ This use of ipse is uncommon outside Cicero (see TLL s.v. ipse $332.13 \mathrm{ff}$.). Is the fact that it is Cicero who uses ipse in this way more often, and also outside his letters, sufficient for us not to regard it as 'colloquial'? The questions raised so far resemble the ones discussed by Adams (Adams et al. 2005).

It is easier to assess the level of formality of a lexical feature in a text if it also occurs elsewhere. I will turn to the word validissime, first attested in Caelius:

quin ego, cum pro amicitia validissime faverem ei..., postquam factum est, obstipui et mihi visus sum captus esse. (Cael. Fam. 8.2.I)

Even I, who as a friend was wholeheartedly on his side ... was dumbfounded when this happened, and felt as though I had been cheated. (trans. D. R. Shackleton Bailey, Loeb)

Cavarzere (1983: 218) seems to regard validissime as the superlative of valde. Valde is often used with verbs as an intensifier, to express a high degree of emotional (placet 'to please') or intellectual (probo 'to approve') appreciation. It is used in this way a few times in Plautus, in combination with placet and deamo 'to love utterly'; Plautus also has valide in the same meaning, for example in combination with amo 'to love'. Plautus has also a few instances of valide and valde in combination with other verbs where it functions as a manner adverb ('vigorously', 'powerfully'), in correspondence with the adjective validus. With the exception of a few instances in Varro it is in Cicero's works, especially his correspondence, that valde is found in large numbers (c. 350 instances: 25 in the orations, 75 in the dialogues, 140 in the letters to Atticus, IIo in the other letters), of which about one quarter occur in combination with gradable adjectives and adverbs. The total number exceeds that of all the other texts on the Bibliotheca Teubneriana Latina CD-ROM together.

Caelius has eight instances of valde in its intensifier meaning, a large number given the size of his corpus. ${ }^{\mathrm{I}}$ From Caesar we have only one instance, in a letter preserved with Cicero's letters (Att. 9.7C.I); the same is true of other correspondents. The form is absent from many other authors, but it occurs in Petronius - once in Encolpius' narrative, five times spoken by a freedman, one has the impression with less restrictions than in Cicero-

${ }^{13}$ Shackleton Bailey translates 'ten clear days' and elsewhere uses the translation 'whole'. This may suggest that ipse is used with a different meaning from usual. Ipse in these contexts indicates that it is 'ten days and nothing else'.

${ }^{14}$ In Fam. 8.I7.2 valde depugnare 'to fight desperately' (paraphrasing Shackleton Bailey's translation), valde is an adverb of manner. 
and also in the Vindolanda Tablets (valde desidero 'I miss you strongly', $347 \mathrm{br}$ ). The 'informal' status of valde therefore looks settled, although it 'should not be overrated, for the word not only occurs in Cicero's letters and dialogues but in the speeches'. ${ }^{\text {Is }}$

As for validissime, Celsus has validissime excitat . . aqua'a most powerful excitant is water' (3.20.3), where it may be taken in its manner meaning 'forcefully' ${ }^{16}$ The form valdissime is found in a letter on papyrus dated 5-2 $\mathrm{BC}$ te valdissime decriminatum [sc. esse] 'that you have been utterly defamed' (Stud. Pal. I4.17.4-5) and in Seneca valdissime diligunt 'they love most devotedly' (Dial. I0.8.4). In Pliny the Younger editors read valdissime, where some of the manuscripts have validissime (five instances in combination with the usual verbs). It looks therefore as if Caelius' use of the non-syncopated form validissime in the sense 'extremely' is unique. Cavarzere (1983: 218), who assumes that Pliny also has the non-syncopated forms, suggests that non-syncopated forms continued to exist after Plautus, but were during the classical period banished to the 'lingua dell'uso, in genere più conservativa'. Our Caelius instance would then be the only manifestation of this continuous stream in the classical period.

But there may be another explanation. On closer examination, the verbs with which Caelius uses valde are very similar to those used by Cicero. The combination valde + faveo does not occur in the classical period, so validissime faverem is also exceptional from this point of view. Although the verb presupposes a certain emotional attitude, it means 'offering (active) support'. Validissime may well be the superlative of valide, the adverb of validus. Caelius was thus a 'fervent supporter'. Of course, this makes the expression no less unique, but there is no need to assume the type of conservative undercurrent that was popular in earlier accounts of the history of Latin. There is a close parallel for this use of valide in Pliny the Elder:

nemo umquam ulli artium validius favit. (Plin. Nat. 30.I4)

No other of the arts ever had a more enthusiastic patron. (trans. W. H. S. Jones, Loeb)

The last lexical item to discuss is suus as found in the manuscript $\mathrm{M}$ in Fam. 8.I4.4 and accepted by Shackleton Bailey:

is Brink 1971 on valdius oblectat in Hor. Ars 321. For Cicero's use of valde see Orlandini 2003. Wölfflin I879 is still useful.

${ }^{16}$ It is used in its meaning 'forcefully' by Ammianus (24.2.10) and in the Historia Augusta (23.4.5). There are a number of instances in Christian authors. Augustine combines it once with amo (Conf. I.IS). 
si sine suo periculo fieri posset, magnum et iucundum tibi Fortuna spectaculum parabat. (Cael. Fam. 8.I4.4)

If it were not for the personal risk involved, Fate is preparing a mighty and fascinating show for your benefit. (trans. D. R. Shackleton Bailey, Loeb)

'Despite the following tibi I retain this reading in the sense of proprio (K.-S. I.606), though if right it is an extreme example of Caelius' careless writing; but cf. Sen. Dial. 9.15.6 ...' (Shackleton Bailey 1977: 433). Most editors, instead of granting Caelius an extreme example of carelessness, have preferred to emend to summo 'extreme' or tuo 'your'. Böhm (I979) has tried to show that summo is in fact how we should interpret the reading of $\mathrm{M}$. I do not believe that Shackleton Bailey's translation 'personal' for suo is possible. The parallels he adduces do not support it, nor does the reference to Kühner-Stegmann. But there may be another way to defend the transmitted reading. Periculum may indicate both the risk that threatens something or somebody or the threat that comes from something or somebody (for the latter meaning see TLL s.v. I469.47 ff.). In both cases the entity involved may be in the genitive, as in the first (omnium) and third (praedonum) example below. For the first ('objective') case it is not difficult to find parallels with a possessive pronoun instead of a genitive, as in the second example below (meo). The TLL has no pronominal parallel for the third ('subjective') example. ${ }^{17}$ The emendation tuo in the Caelius text is evidently an attempt to supply a threatened person ('objective').

... quis hoc statuit umquam aut cui concedi sine summo omnium periculo potest, ut eum <iure potuerit occidere, a quo metuisse se dicat ne ipse posterius occideretur? $>$ (Cic. Tul. 5I)

... who ever laid down such a principle as this, or who could have this granted him without extreme danger to the whole body of citizens, that he might lawfully kill a man, if he only said that he was afraid of being hereafter killed by him? (trans. C. D. Yonge)

at enim non sine meo periculo, Crassus inquit, possum, Sulpici, te reprehendere, quoniam Antonius mihi te simillimum dixit sibi videri. (Cic. De orat. 3.47)

'All the same,' said Crassus, 'I can't find fault with you without running some risk on my own account, because Antonius said that in his view you and I are extremely like one another.' (trans. H. Rackham, Loeb)

${ }^{17}$ For the use of possessive pronouns for 'objective' relations see also K-S I.599. TLL s.v. meus 92I.I2 ff. refers to the frequent use of meus 'mine' for a 'subjective' relation. There is no precise parallel. 
nam aestate summa, quo tempore ceteri praetores obire provinciam et concursare consuerunt aut etiam in tanto praedonum metu et periculo ipsi navigare ... (Cic. Ver. 5.80)

During the height of summer, the season when it has been the practice of all other governors to move actively about and inspect their province, or even, when the risk of attacks by pirates was as formidable as it then was, to put to sea themselves ... (trans. L. H. G. Greenwood, Loeb)

Turning now to suo, we may first ask whether sine periculo tout court would do as well (it would, as in the example that follows) and, then, what suo adds.

cum ei dicerem tibi videri sponsionem illam nos sine periculo facere posse... (Cic. Fam. 7.21.I)

When I told him that in your opinion we could safely make the stipulation... (trans. D. R. Shackleton Bailey, Loeb)

The referent of the reflexive possessive pronoun, unlike meus and tuus, has to be found in its immediate context. It is often the subject of the clause in which it occurs, but it may be another constituent of that clause, and it may also be the subject of the immediately governing clause. There are in fact even more possibilities (see Bertocchi 1989; K-S I.600-17). In our case suo cannot be related to a constituent of its own clause. The first candidate to relate it to is Fortuna in the main clause. Evidently suo periculo cannot be interpreted as 'the risk that threatens Fortuna itself (an 'objective' interpretation), but maybe it means 'the risk that emanates from Fortuna itself. At this point we return to Kühner-Stegmann, not to the page Shackleton Bailey refers to, but to page I.599, Anm. 6, where they draw attention to the fact that the Latin possessive pronoun has a wider range of meanings than the German one. The OLD s.v. suus in has examples under the heading 'his distinctive or characteristic'. Sine suo periculo means 'without the risk that is typically involved when Fate does its work'.

The result of the preceding discussion is still a unique expression. But if the reader agrees that it is entirely in accordance with the semantic and syntactic rules of Latin there is nothing wrong with it being a unique expression. That does not make it 'colloquial', and it is certainly better to look for an explanation along the rules of Latin than to defend it as an extreme example of carelessness.

I now turn to a few syntactic items. First a few remarks about sentence structure. It is difficult to make a comparison between the sentences of Caelius and Cicero in their mutual correspondence. The first difficulty 
consists in the fact that we have to decide what counts as a sentence. If we define a sentence as a string of words between two periods and include strings that are separated by one or more semicolons, the results are affected by the fact that Shackleton Bailey has relatively more semicolons in Caelius' text than in Cicero's. If we use a syntactic definition, as I do for this purpose, and consider a sentence a string of words that has no syntactic interdependence with a preceding or following string, then the strings separated by semicolons will count as sentences. This is not as easy as it seems at first sight, because in the case of asyndetic co-ordination one might opt for independent sentences instead of clauses. It is also difficult to make a distinction between (explicitly) co-ordinated clauses (belonging to one sentence) and co-ordinated sentences; in spoken language it is usually not difficult to hear the difference. Essentially I follow Shackleton Bailey's decisions (also his deletions and additions) and equate his semicolons with full stops. ${ }^{18}$ The second difficulty consists in establishing the number of clauses that make up a sentence. I count as clauses the main and finite subordinate clauses as well as participial clauses (predicative participles and ablative absolutes), gerundi(v)al clauses, and accusative and infinitive clauses, including those lacking a verb.

Working in this way I found that on average Caelius' sentences are longer in terms of the number of words they contain (Caelius I4.3 words per sentence, Cicero I2.8), and are more complex in terms of the number of clauses per sentence (Caelius 2.8, Cicero 2.4). Conversely, Cicero has more words per clause (5.4) than Caelius (5.0). If one examines sentence length in more detail, it turns out that Cicero has more (very) short sentences (25 per cent are between one and five words, 35 per cent between six and ten), Caelius more sentences of $\mathrm{II}-\mathrm{I} 5$ words and also more very long sentences. This can be seen in the radar diagram below (Figure II.I). In this diagram 7 types of sentence length are distinguished (from $\mathrm{I}-5$ words to 3I-60 words) and for each type the percentage is indicated (running from o per cent in the middle to 35 per cent at the outside).

The number of predicative participles in Caelius is almost twice as great as in Cicero (20.2 per cent of all clauses, versus 4.I per cent of all clauses), and Caelius has many more ablative absolutes (I3 versus I). Why? My estimate is that this has to do with the fact that there is more narrative in Caelius, which is not strange in the light of the communicative goal of his

I8 The result of this approach is the following. Number of sentences: Caelius 369 , Cicero 158 . Number of clauses: Caelius I,048, Cicero 376. 




Cicero

Caelius

Fig. II.I Sentence length in Cicero and Caelius

letters in comparison with Cicero's. ${ }^{19}$ At the same time the frequency of these clause types contributes to the fact that on average Caelius' clauses are shorter.

Caelius and Cicero have practically the same amount of clauses that are 'encapsulated' in their governing clause (Caelius 87 clauses, 7 per cent of all clauses; Cicero 26 clauses, also 7 per cent). I give one example below with two encapsulated clauses. I find this form of sentence building more difficult to read than a form in which clauses follow each other, and it may be more sophisticated. This has no obvious connection with the degree of formality of the structure:

atque hoc e[g]o diligentius facio quod, cum otiosus sum, plane ubi delectem otium meum non habeo. (Cael. Fam. 8.3.I)

I am all the more punctilious about it, because when I have no work at hand there is simply nowhere for me to amuse my leisure. (trans. D. R. Shackleton Bailey, Loeb)

More remarkable is the relative frequency of complement clauses that precede their main clause in Caelius (29, 2.7 per cent of all clauses, versus Cicero 6, I.5 per cent). Two examples are given below. The relative order of main and subordinate clauses is (partly) determined by discourse factors: the clause with topical information, that is information related to the

\footnotetext{
I9 For the ablative absolute as a typical feature of narrative discourse see Paschoud and Wirz 2007.
} 
preceding discourse or otherwise accessible to the reader, has the best chance of coming first. The material is insufficient to arrive at firm conclusions.

mea porro comitia quem eventum sint habitura nescio. (Cael. Fam. 8.4.3)

What is going to happen in my own [elections] I don't know. (trans. D. R. Shackleton Bailey, Loeb)

tu si Pompeium, ut volebas, offendisti, qui tibi visus sit et quam orationem habuerit tecum quamque ostenderit voluntatem (solet enim aliud sentire et loqui neque tantum valere ingenio ut non appareat quid cupiat), fac mihi perscribas. (Cael. Fam. 8.I.3)

If you found Pompey, as you wanted to do, be sure to write and tell me what you thought of him, how he talked to you, and what disposition he showed. He is apt to say one thing and think another, but is usually not clever enough to keep his real aims out of view. (trans. D. R. Shackleton Bailey, Loeb)

In the example given below a constituent of the subordinate clause $(t u)$ is placed at the beginning of the sentence in a clause to which it does not belong. This phenomenon is called 'fronting' or 'topicalisation'. In a way it resembles the sentence structure of the preceding examples in that topical information is placed early in the sentence. This structure is often considered 'colloquial'. There are seven instances in Cicero and only eleven in Caelius.

tametsi tu scio quam sis curiosus et quam omnibus peregrinantibus gratum sit minimarum quoque rerum quae domi gerantur fieri certiores. (Cael. Fam. 8.I.I)

However, I know how curious you are and how much everybody abroad likes to be told of even the most trifling happenings at home. (trans. D. R. Shackleton Bailey, Loeb)

Another 'colloquial' feature, recently discussed by Adams (I995b: II7-I8, 2003c: 19), is the use of the second person subjunctive without $u t$ with verbs like rogo 'to ask' to express a request or instruction. Caelius has it in combination with fac (an example is given above) and with velim 'I'd like' (twice), which Cicero uses three times, more or less set directive expressions.

Caelius uses rogo without $u t$ once (see below), whereas Cicero has one instance of the 'formal' (Adams) rogo ut (Fam. 2.IO.4), or rather $u t$. . rogo, as almost always in his letters. Caelius has peto 'to request' once. Cicero uses it often, seventy times in his letters (not in our corpus). He uses it with $u t$ sixty-four times, without $u t$ - probably - in order to avoid repetition of 
$u t$ four times, and only two times without such a reason. ${ }^{20}$ Caelius also has moneo 'to warn' (once), ${ }^{2 \mathrm{I}}$ possibly admoneo (Cael. Fam. 8.4.5), and suadeo 'to advise' (twice), which Cicero has in a letter to Caelius of a later date (Fam. 2.16.7). ${ }^{22}$

The bare subjunctive is also found outside the class of verbs discussed so far. Cicero has oportet 'it is proper' only once in these letters (Fam. 2.I4), but that is nevertheless the regular expression. Caelius uses impetro 'to obtain' once without $u t$ (see below), a very uncommon usage throughout latinity. ${ }^{23}$ Lambinus proposed to read $u$ treprehenderem. Remarkable is not only the absence of $u t$ but also the length and the complexity of the subordinate clause and the fact that it precedes its governing verb:

sed quoniam suspicaris minus certa fide eos <esse quos $>$ tibi misi, tamquam procurator sic agas rogo. (Cael. Fam. 8.Ir.4)

But since you suspect that the persons I sent are not altogether trustworthy, please act as though you were my agent. (trans. D. R. Shackleton Bailey, Loeb)

postea quam vero comperi eum collegam temptasse... ipsum reprehenderem et $\mathrm{ab}$ eo deprecarer iniuriam quem vitam mihi debere putaram impetrare a me non potui. (Cael. Fam. 8.I2.I)

But when I found that he had been sounding his colleague... I could not bring myself to tax him personally and ask a man who I thought owed me his life not to do me harm. (trans. D. R. Shackleton Bailey, Loeb)

Apart from fac, velim and oportet, where there was no real choice, Caelius had the choice between the $u t$ expression and the bare subjunctive. In the letters we have and which I discuss he opted for the bare subjunctive, even in the last example in which some form of formal demarcation of the subordinate clause would seem easier for the reader. This means on the one hand that the recipient of the letter (Cicero) was capable of processing the text, and on the other hand that the degree of transparency of the sentence structure created by the use of $u t$ was not felt necessary by every educated writer. Was Caelius 'informal' or was Cicero 'overformal'? The

${ }^{20}$ Avoidance of repetition can be suggested for Cic. Att. 3.25 illud abs te peto des operam ut... (by contrast, ... a te peto ut des operam ... ne ... - Fam. 15. I2. 2); Fam. I3.34.I, I3.39.I, 13.55.2. The two other bare subjunctives are in Fam. 15. $\overline{8}$ and I6.I4.2.

${ }^{21}$ Moneo + subjunctive is found elsewhere in Cicero (see also TLL s.v. moneo I4II.9 ff.).

${ }^{22}$ Cicero advises Caelius with respect to his attitude towards Dolabella, the same context in which Caelius had used suadeo + bare subjunctive before. Cicero has suadeo without $u t$ also in Fam 7.7.I. Caelius uses censeo 'to recommend' once with a bare subjunctive in a later letter (8.I6.5). This use of censeo is common from Plautus onwards and is best regarded as a set phrase (material in TLL s.v. censeo 794.23).

${ }^{23}$ TLL s.v. 6or.5o has Pl. Trin. 59I and a few other, non-literary or late, instances. 
last example is especially interesting in this context. Are we to assume that in spontaneous spoken language such a sentence would have been interpretable and was it even typically colloquial? Or is it written language dictated by a very good public orator who uses an option that Cicero did not use that often?

The next item I want to discuss is the extent to which both authors separate modifiers from the nouns to which they belong (i.e. hyperbaton or discontinuity of a noun phrase). I make a distinction between three types of hyperbaton: (i) hyperbaton caused by an intervening particle like enim 'you know' or quidem (see below), (ii) hyperbaton caused by a constituent that is neither a particle nor part of the noun phrase, (iii) hyperbaton by multiple constituents that are not part of the noun phrase. Discontinuity is a characteristic feature of the Latin noun phrase (see C. Lehmann I99I). Type (i) is more or less unavoidable. The other two are optional and more interesting when the language of different authors is examined. Examples of the three types are given below:

Plancus quidem tuus Ravennae est... (Cael. Fam. 8.I.4)

Your friend Plancus is at Ravenna... (trans. D. R. Shackleton Bailey, Loeb)

si quid in re publica maius actum erit... et quem ad modum actum sit et quae existimatio secuta quaeque de eo spes sit diligenter tibi perscribemus. (Cael. Fam. 8.I.2)

If there is any major political event... I shall be careful to write you a full account of the manner of it and of consequent views and expectations. (trans. D. R. Shackleton Bailey, Loeb)

illud nunc a te peto, si eris, ut spero, otiosus, aliquod ad nos, ut intellegamus nos tibi curae esse, $\sigma u ́ v \tau \propto \gamma \mu \alpha$ conscribas. (Cael. Fam. 8.3.3)

Now I have a favour to ask. If you are going to have time on your hands, as I expect you will, won't you write a tract on something or other and dedicate it to me, as a token of your regard? (trans. D. R. Shackleton Bailey, Loeb)

The relative frequency of the three types can be seen in the graph below (Figure II.2), in which the absolute numbers have been adjusted on the basis of the number of words of the two corpora (and not the number of noun phrases). Caelius has more instances of type (iii), but they are not rare in Cicero, who, elsewhere, has instances with a very long distance between the separated constituents (Adams 1971: 13). The attributes involved and the pragmatic reasons to separate them from their heads are the same 


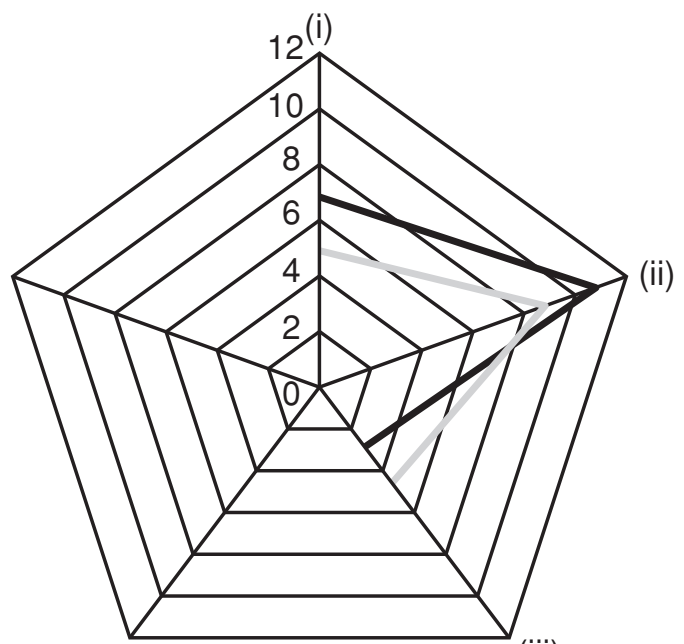

(iii)
Cicero

Caelius

Fig. II.2 Hyperbaton in Cicero and Caelius

in both authors. ${ }^{24}$ Caelius seems to have found more reason to use this option.

A common feature of letters are expressions that indicate transition to another subject. Prepositional phrases with de 'about' serve that purpose and so do subordinate clauses introduced by quod. An explicit form of attracting the attention for a new topic with quod attinet ad 'as for' is shown in the first example below (six instances in Caelius, only three in Cicero's letters). In the other example quod alone signals 'Now for something new/different', remarkably enough at the beginning of the first letter of the exchange of letters during Cicero's stay abroad:

quod ad tuum decessum attinet, illud tibi non possum polliceri, me curaturum ut tibi succedatur. (Cael. Fam. 8.IO.5)

As regards your departure from Cilicia, I cannot promise to procure the appointment of a successor. (trans. D. R. Shackleton Bailey, Loeb)

quod tibi decedens pollicitus sum me omnis res urbanas diligentissime tibi perscripturum, data opera paravi qui sic omnia persequeretur ut verear ne tibi nimium arguta haec sedulitas videatur. (Cael. Fam. 8.I.I)

Redeeming the promise I made as I took my leave of you to write you all the news of Rome in the fullest detail, I have been at pains to find a person to cover the

${ }^{24}$ Absolute numbers for type (i) Caelius I3, Cicero 7; (ii) 24:II; (iii) I2:3. 
whole ground so meticulously that I am afraid you may find the result too wordy. (trans. D. R. Shackleton Bailey, Loeb)

Caelius uses quod expressions seven times, while there is no instance of this construction in the letters of Cicero discussed here (though Cicero uses it elsewhere, especially in contexts like quod scribis... as for your observation...'). ${ }^{25}$ The use of such expressions is sometimes considered 'colloquial'. Although I do not doubt that they were also used in spoken language, they are not a 'colloquial' feature, nor are they especially 'informal'. Transitional signals are a necessary feature in any form of longer discourse. The fact that Caelius has more of them than Cicero probably is to do with the different roles the two had in their communication.

To conclude: it is difficult and often wrong to apply the notion 'colloquial' to the language of letters in general and to Caelius' letters in particular. We may assume that his letters show an informal way of writing. Most of the features involved are not unique to Caelius, although he uses some expressions more often than Cicero. Lexical items are particularly risky to establish the level of formality of a text, since they are closely connected to subject matter. Caelius' language sometimes seems to be evaluated more on the basis of what we know about his personality and the few remarks in Tacitus than on the basis of the data.

${ }^{25}$ For the use of this type of quod clause in Cicero's correspondence see Garcea 2003b. 